\title{
Comparative Assessment of Some Physicochemical Properties of Different Sesame Varieties and Oil Yield, Ethiopia
}

\author{
Mulate Zerihun ${ }^{1, ~ *}$, Hayelom Berhe ${ }^{2}$ \\ ${ }^{1}$ Melekassa Agriculture Research Center, EIAR, Addis Ababa, Ethiopia \\ ${ }^{2}$ National Fishery and Aquatic Life Research Center, Sebeta, EIAR, Addis Ababa, Ethiopia \\ Email address: \\ mulatezerihun@yahoo.com (M. Zerihun), berhehayelom18@gmail.com (H. Berhe) \\ ${ }^{*}$ Corresponding author
}

To cite this article:

Mulate Zerihun, Hayelom Berhe. Comparative Assessment of Some Physicochemical Properties of Different Sesame Varieties and Oil Yield, Ethiopia. Bioprocess Engineering. Vol. 4, No. 1, 2020, pp. 23-28. doi: 10.11648/j.be.20200401.14

Received: January 13, 2020; Accepted: February 27, 2020; Published: May 29, 2020

\begin{abstract}
The proximate composition and physico chemical properties of released and improved Ethiopian sesame oil seed crops were evaluated. The results of statistical analyses showed significant variations in proximate composition values and physico chemical characteristics of sesame oil seed crops. The analysis of variance indicated that moisture content was ranged between $4.4 \%$ to $4.8 \%$, total ash $(4.70 \%$ to $8.72 \%$ ), crude protein content $(14.44 \%$ to $21.51 \%)$, crude fat /oil $(44.40 \%$ to $50.84 \%)$ and carbohydrate was ranged between $(16.23 \%$ to $29.46 \%)$. Maturity stage and storage conditions are the major factors for moisture contents. The lower moisture values indicated that there is low vulnerable for oil spoilage the so-called rancidity. Total ash values are the indication of inorganic elements that are present in food as minerals. From the ash values, comparatively Tate has a better mineral value as compared with others. Serkamo sesame variety has a better protein value while the minimum (14.44\%) was recorded at Adi. This may due to the reason that protein values have direct correlation with agronomic practices. The oil contents of seed crops were significantly different; this may be due to genetic difference. The carbohydrate values have significant difference among varieties. These variations may be bringing form the concept that oil crops mostly have a better oil values, thus subtractions of carbohydrate from the proximate values have a significant effect on the carbohydrate's values. On the other hand, the oil characterization of seed crops indicated that the range of saponification value was between ( 184.47 to $199.60 \mathrm{mgKOH} / \mathrm{g}$ ), specific gravity ( 0.85 to 0.90$)$, thousand seed weight ( 2.72 to $3.63 \mathrm{~g}$ ), free fatty acid value ( 7.63 to $16.67 \%$ ), ester value ( 151.32 to 182.90$)$ and acid value (15.18 to $33.15 \mathrm{KOH} / \mathrm{g})$. The physico chemical parameters of sesame oil seed crops were significantly different among varieties. This variation mainly exists due to genetic variabilities among the seed crops. From these ten different sesame varieties, Abasena with its lowest saponification value and high free fatty acid value indicated that the oil from this variety is regarded non-edible oil. Lower acid value indicated the oil stability against peroxidation. Abasena with its higher acid value indicated that the oil is not suitable for cooking as compared with the remain sesame varieties.
\end{abstract}

Keywords: Sesame, Varieties, Quality, Physicochemical Properties, Oil Contents

\section{Introduction}

Sesame (SesamumindicumL.) is one of the most ancient oilseed crops known to mankind and cultivated plant and thought to have originated from Africa and India. Sesame is one of the most important oilseeds crops worldwide. It is an important oilseed crop grown for local consumption and export in Ethiopia and it is the first in area of production and as export oil crop among oilseed crops in Ethiopia [1]. Ethiopia is among the world's top five producers of sesame and the third largest world exporter of the crop [2]. In Ethiopia, the production of sesame is both by small- and large-scale farmers; and it is an important crop and export commodity. Oilseed crops are major sources of lipids for human nutrition as well as for several industrial purposes. They are defined as those seeds that contain considerably 
large amounts of oil. The most commonly known oilseeds (conventional oil seeds) are groundnut, soybean, palm kernel, cotton seed, olive, sunflower seed, sesame seed, linseed, etc. [3]. Sesame is an oil crop known by different names such benniseed (Sesamum indicum) in Nigeria, simsim, til [4].

It is cultivated widely in India, Burma, Indo-China, Japan and some parts of Africa, the Mediterranean and, more recently, in the USA, Mexico and other Latin American countries [4]. The seeds of different varieties have various colors, such as creamy white, dark red, brown, and yellow [5]. Among the important uses of sesame seed is the production of high quality odorless vegetable oil, which can substitute for olive oil [6]. The oil has found many uses in industry e.g. for manufacture of soap, cosmetics, perfume and pharmaceutical products [6]. The oil contains, in addition to phytosterol and tocopherol, two compounds which are not found in any other oil, namely sesamolin; this, upon hydrolysis, yielded sesamol, which is responsible for the antioxidant behavior of sesame seed crop oil [4].

There are numerous varieties and ecotypes of sesame adapted to various ecological conditions. Sesame is cultivated on a worldwide basis for both oil and protein. The seed contains nearly $25 \%$ protein, and the defatted meal contains nearly $50 \%$ protein. Sesame seed can be crushed and the oil produced can be used principally as a salad or cooking oil. Certain grades of sesame seed which are white and have a larger sized grain are used extensively in the cuisines of the Middle East and Asia and as a flavoring on bakery and other confectionery items in Europe and North America.

Sesame is primarily grown by small farmers in Ethiopia. Crop development programs in Ethiopia are small and little progress has been made during the past 50 years. In the oil industry, sesame is commonly used as the raw material for oil extraction, either using organic solvents or by mechanical pressing. Since the sesame meal product after oil extraction have approximately $50 \%$ protein and is usually used as a fed to animals as a protein source. This meal has high potential for use as a protein source or as an ingredient in the food industry. Sesame protein isolates or concentrates normally are prepared by isoelectric precipitation and salt precipitation. If a sesame protein ingredient is going to find widespread application as an ingredient in the food industry, it is important to know its functional properties, for example solubility, water holding capacity, fat absorption capacity, emulsifying properties and foaming properties. Few studies have been done on the functional properties of sesame proteins from defatted sesame meal. A revitalization of sesame research using modern plant breeding knowledge and new technologies could be of great value in improving the crop. Research in Werer Agricultural Research Center, Ethiopia has developed ten sesame varieties but information concerning quality of those released varieties is not available. Therefore, studying quality parameters of released sesame varieties is quite important in increasing value of the varieties.

\section{Materials and Methods}

\subsection{Description of the Study Area}

The study was carried out at Werer Agriculture Research Center (WARC). The site is located in the Afar National Regional State, Amibara Woreda at Melka Werer town, which is $280 \mathrm{~km}$ in the north east of Addis Ababa. It is located at $9^{\circ} 60^{\prime} \mathrm{N}$ latitude and $40^{\circ} 9^{\prime} \mathrm{E}$ longitude and at an altitude of $740 \mathrm{~m}$. a. s. 1. The center is characterized by low and erratic rainfall with total annual rainfall of $564 \mathrm{~mm}$ which is less than the total annual average evapotranspiration of $2050 \mathrm{~mm}$. Light textured alluvial and black soils with a $\mathrm{pH}$ of 8.4 are the dominant soil types of the center. The mean annual temperature is $34.1^{\circ} \mathrm{C}$ with a minimum of $18.9^{\circ} \mathrm{C}$ and maximum of $38^{\circ} \mathrm{C}$, respectively.

\subsection{Sample Collection}

A total of ten Sesame oil seed crop varieties were collected from Werer Agricultural Research Center which were released and improved before.

\subsection{Sample Analysis}

\subsubsection{Determination of Moisture Content}

Moisture contents of sesame varieties were analyzed using oven dry method according to AOAC, 2000 official method 925.09 [7]. Crucibles were cleaned and dried in an ovendry method at $105^{\circ} \mathrm{C}$ for 1 hour and placed in desiccators and moisture was removed. Weight of crucible (W1) was determined. $5 \mathrm{~g}$ samples of sesame were weighed in the dry crucible (W2) and dried at $135^{\circ} \mathrm{C}$ for 1 hour and after cooling the sample in desiccators to room temperature was weighed again (W3). Finally, the moisture content of sample was calculated using the equation below:

$$
\% \mathrm{MO}=\frac{\mathrm{W} 2-\mathrm{W} 3}{\mathrm{~W} 2-\mathrm{W} 1} \times 100
$$

Where:

$\% \mathrm{MO}=$ percentages of moisture content

$\mathrm{W}_{1}=$ weight of the empty crucible

$\mathrm{W}_{2}=$ weight of the crucible plus weight of fresh sample

$\mathrm{W}_{3}=$ weight of the crucible plus weight of the sample after oven dried

\subsubsection{Determinations of Total Ash Contents}

The ash content was determined by (AOAC) [8] using the official method 923.03. Porcelain dishes were placed in a muffle furnace for $30 \mathrm{~min}$ at $550^{\circ} \mathrm{C}$. The dishes were cooled in desiccators (with granular silica gel) for some minutes at room temperature and weighed (W1). $5 \mathrm{~g}$ of crushed fresh sample was weighed (W2). Finally, the crucibles with the weighed sample were placed on a hot plate under a fumehood and the temperature was slowly increased and the samples become thoroughly charred. Then dishes with sample (charred) were placed inside the muffle furnace at $550^{\circ} \mathrm{C}$ for 5 hours. After the time finished the crucible was cooled in desiccators for 1 hour and reweighed (W3). Total 
ash content was determined using the formula below:

$$
\% \mathrm{Ash}=\frac{W 3-W 1}{W 2-W 1}
$$

Where:

$\%$ Ash $=$ percentages ash content

$\mathrm{W}_{1}=$ weight of the empty dishes

$\mathrm{W}_{2}=$ weight of the dishes plus weight of fresh sample

$\mathrm{W}_{3}=$ weight of the crucible plus weight of the sample after oven dried

\subsubsection{Crude Protein Contents of Sesame Varieties}

Sesame crude protein content was determined through Kjeldhal method according to official method of AOAC, number 979.09, using FOSS kjeltec 8400 [9]. Air dried sample of $1 \mathrm{~g}$ was taken in a tecator tube and $15 \mathrm{ml}$ of concentrated sulfuric acid was added and mixed. Then 2 tablets of 1000 kjeltabs $\mathrm{Cu} / 3,5$ mixture of catalyst was added into each tube, and allowed to digest using FOSS digester at $420^{\circ} \mathrm{C}$ for 1 hour. The digestion was allowed and a clear solution was obtained at about 1 hours. The distillation and titration process were carried out using FOSS kjeltec 8400 digital machine having receiver solution of $40 \%$ of sodium hydroxide and $0.1 \mathrm{~N}$ of hydrochloric acid as titrant solutions and deionized water. During this analysis ammonium iron (II) sulphate hexa hydrate $(0.15 \mathrm{~g})$ with theoretical nitrogen values of ammonium sulphate $(21.09 \%)$ was used to check the recovery. The percentages of crude protein were calculated by the FOSS Kjetec 8400 digitally using the conversion factors of 6.25 in triplicate form and the general formula used for calculations of crude protein was described below.

$$
\% \mathrm{~N}=\frac{(\mathrm{VHCl} \text { sample }-\mathrm{VHCl} \text { blank }) \times \mathrm{N} \mathrm{HCl} \times 14.0}{\text { Wight of sample }(\mathrm{g})} \times 100
$$

After the crude protein was determined using equation in the above, the percentage protein content of sesame varieties were determined using conversion factors of 6.25 , $(\%$ Protein $=\% N \times 6.25)$

Where:

$\% \mathrm{~N}=$ Percent of nitrogen

$\mathrm{V} \mathrm{HCl}=$ Volume consumed by the sample in liter to the end point of titration,

$\mathrm{V} \mathrm{HCl}$ blank=Volume consumed by the blank (without sample)

$\mathrm{N}=$ normality of $\mathrm{HCL}(0.1 \mathrm{~N})$,

$\mathrm{Wt} .=$ Weight of sample in gram and 14.0=Molecular weight of nitrogen

\subsubsection{Crude Fat/Oil Contents of Sesame Varieties}

The crude fat content of crushed sesame sample was determined using soxtec ${ }^{\mathrm{TM}}$ 8000, FOSS extraction using official method of (AOAC, 2000) 920.39using n-hexane as extraction solvent using official method 4.5.01 [10]. $2 \mathrm{~g}$ of crushed sesame was weighed using thimble and covered with purified cotton. Then $50 \mathrm{ml}$ of petroleum ether was added as a solvent. The sample with the solvent was placed in the soxtec extractor for 1 hour. After 1 hour the extra or residual solvent was evaporated using oven dry method at $103^{\circ} \mathrm{C}$ and the pure extracted fat was cooled in a desiccator and weighed. Then crude fat was calculated using equation below. Then the extracted oil was used for the determinations of physico-chemical properties of sesame varieties.

$$
\% \text { Crude fat }=\frac{\text { Weight of deried fat }}{\text { Fresh sample }(\mathrm{g})} \times 100
$$

\subsubsection{Determinations of Carbohydrate Content}

The amount of carbohydrate content of sesame oil crops were determined by difference, by subtracting the summations of moisture, ash, crude protein, crude fat, and crude protein contents from 100 , as described in the equation below.

$\%$

$$
\begin{aligned}
& \mathrm{CHO}=100-(\% \text { mositure }+\% \text { fat }+\% \text { protien }+\% \text { ash }) \\
& \text { Where: } \% \mathrm{CHO}=\text { percentage of carbohydrate }
\end{aligned}
$$

\subsection{Physico-chemical Properties of Sesame Varieties}

After the oil was extracted by AOAC official method [10] using the n-hexane as solvent, the extra hexane (solvent) was removed using rotary evaporator. The extracted oil was used for determinations of physico-chemical analysis of oils of sesame varieties. Saponification value was determined using AOAC (2000) [11]. The acid value was determined using Ronald (1991) method [11]. Whereas the refractive index was analyzed using the method $[11,12]$. The specific gravity and ester values of sesame varieties were determined $[13,14]$ respectively.

\subsection{Statistical Analysis}

Data were statistically analyzed using SPSS 20.0 Window evaluation version program with Duncan's multiple range post-hoc test and all measurement parameters were done in triplicate form and the data was reported as mean \pm standard deviation (SD) at $95 \%$ confidence level.

\section{Result and Discussion}

\subsection{Proximate Compositions of Sesame Varieties}

The proximate composition parameters are presented in Table 1. The analysis of variance indicated that moisture content (Table 1) showed slightly significant differences among sesame varieties. The maximum moisture content was recorded in T-85 (4.8\%) followed by Argene (4.7\%). Thus, the moisture content mostly depends on the maturity stage and the storage conditions for the varieties; this is may be the reason that the moisture contents of sesame varieties become low. But low moisture content has an advantage on the reductions of oil spoilage the so-called rancidity. The range of moisture content of sesame seeds in the present work is in close agreement with the data presented at [15] for different sesame varieties.

Ash in sesame varieties is an indication of inorganic elements that are present in food as minerals. The ash content 
of sesame varieties has a highly significant $(\mathrm{P}<0.001)$ difference among the Sesame varieties. Generally, the ash contents ranged between $4.5 \%-8.72 \%$ of $\mathrm{T}-85$ and Tate respectively which were not in agreements with the ash contents of Turkish sesame varieties reported in the ranges $3.88 \%$ to $5.39 \%$ [15].

Protein content was significantly $(\mathrm{P}<0.01)$ affected by Sesame varieties (Table 1). The crude protein contents have direct relations with $\mathrm{N}$ fertilizer applications include agronomic practices and soil microbiological enzymes used for mineralization of organic matter which are source of nitrogen. The protein content ranged from $14.44 \%$ to $21.51 \%$ based on dry weight base from Serkamo and Adi respectively and average mean was $18.25 \%$ which is comparable with the results reported from Nigerian bennised and Turkish sesame varieties $[15,16]$.

The analysis of variance showed that; T-85 have the minimum $(44.40 \%)$ oil cotenant, while the maximum (50.84\%) oil content was recorded from Abasena sesame seed crop which have a better oil content and clos in agreement with result presented for the yellow color of Nigerian bennised seed with oil content of53.8\% [16]. The crude fat content of Sesame varieties have slightly significant $(\mathrm{P}<0.001)$ difference among varieties and this may be due to the genetic variability of the crop types [17]. The gray color Abasena sesame variety is particularly rich in oil compared to the other varieties (Table 1). Therefore, oil crops having greater percentages of oil contents become preferable for oil productions.

The carbohydrate content of Sesame varieties were determined by difference from $100 \%$ using the summations of proximate composition values of moisture, ash, crude protein and crude fat. Both T-85 (29.46\%) and E (29.08\%) have the maximum carbohydrate contents followed by $16.23 \%$ (Abaseana) which has the lowest carbohydrate contents among all sesame varieties. The mean average value of carbohydrate content is $23.15 \%$ (Table 1) and the analysis variance indicated that the carbohydrate contents were better than the results reported by Dashak [16]. The variations in values of carbohydrate may be bring form the concept that oil crops mostly have a better oil values, thus subtractions of carbohydrate from the proximate values have a significant effect on the percentage's values of carbohydrates.

Table 1. Percentage of proximate composition parameters of sesame oil seed corps.

\begin{tabular}{lllllll}
\hline Varieties & Color & Mo (\%) & Ash (5) & Pr (\%) & C. Fat (\%) & CHO (\%) \\
\hline T-85 & Dull white & $4.80 \pm 0.000^{\mathrm{a}}$ & $4.50 \pm 0.400^{\mathrm{g}}$ & $16.84 \pm 0.365^{\mathrm{f}}$ & $44.40 \pm 0.419^{\mathrm{e}}$ & $29.46 \pm 0.453^{\mathrm{a}}$ \\
Kalafo-74 & Dull white & $4.50 \pm 0.100^{\mathrm{cd}}$ & $7.46 \pm 0.050^{\mathrm{b}}$ & $19.54 \pm 0.440^{\mathrm{c}}$ & $47.08 \pm 0.410^{\mathrm{cd}}$ & $21.42 \pm 0.030^{\mathrm{de}}$ \\
E & Dull white & $4.40 \pm 0.200^{\mathrm{de}}$ & $6.12 \pm 0.120^{\mathrm{f}}$ & $16.04 \pm 0.290^{\mathrm{g}}$ & $44.36 \pm 0.250^{\mathrm{e}}$ & $29.08 \pm 0.270^{\mathrm{a}}$ \\
$\mathrm{S}$ & Mixed & $4.50 \pm 0.100^{\mathrm{cd}}$ & $7.07 \pm 0.070^{\mathrm{d}}$ & $18.38 \pm 0.290^{\mathrm{e}}$ & $46.00 \pm 0.341^{\mathrm{d}}$ & $24.05 \pm 0.121^{\mathrm{c}}$ \\
Mehalo-80 & Gray & $4.50 \pm 0.100^{\mathrm{cd}}$ & $7.20 \pm 0.060^{\mathrm{cd}}$ & $18.80 \pm 0.000^{\mathrm{d}}$ & $47.38 \pm 1.580^{\mathrm{c}}$ & $22.11 \pm 0.420^{\mathrm{d}}$ \\
Abasena & Gray & $4.60 \pm 0.000^{\mathrm{bc}}$ & $7.33 \pm 0.170^{\mathrm{bc}}$ & $21.00 \pm 0.150^{\mathrm{b}}$ & $50.84 \pm 1.190^{\mathrm{a}}$ & $16.23 \pm 0.200^{\mathrm{g}}$ \\
Argene & Mixed & $4.70 \pm 0.100^{\mathrm{ab}}$ & $7.20 \pm 0.110^{\mathrm{cd}}$ & $18.52 \pm 0.150^{\mathrm{de}}$ & $49.20 \pm 0.070^{\mathrm{b}}$ & $20.43 \pm 0.893^{\mathrm{c}}$ \\
Adi & White & $4.49 \pm 0.090^{\mathrm{cd}}$ & $6.03 \pm 0.020^{\mathrm{f}}$ & $21.51 \pm 0.071^{\mathrm{a}}$ & $48.86 \pm 0.970^{\mathrm{b}}$ & $19.11 \pm 0.655^{\mathrm{f}}$ \\
Serkamo & Mixed & $4.40 \pm 0.000^{\mathrm{de}}$ & $6.47 \pm 0.050^{\mathrm{e}}$ & $14.44 \pm 0.000^{\mathrm{h}}$ & $47.02 \pm 0.060^{\mathrm{cd}}$ & $27.67 \pm 0.855^{\mathrm{b}}$ \\
Tate & Dull white & $4.30 \pm 0.100^{\mathrm{e}}$ & $8.72 \pm 0.030^{\mathrm{a}}$ & $16.84 \pm 0.070^{\mathrm{f}}$ & $48.19 \pm 0.580^{\mathrm{bc}}$ & $21.95 \pm 0.701{ }^{\mathrm{d}}$ \\
Mean & & 4.52 & 6.80 & 18.19 & 47.33 & 23.15 \\
LSD $(0.05)$ & & $0.18 * * *$ & $0.25 * * *$ & $0.32 * * *$ & $1.22^{* * *}$ & $1.21^{* * *}$ \\
\%CV & & 2.13 & 2.10 & 1.03 & 1.51 & 3.04 \\
\hline
\end{tabular}

Values are the means of triplicate experiments and reported as mean \pm S. D. CV $(\%)=$ Coefficient of variation, $S . D=$ standards of deviation of means, means in the same column and within the same treatment category followed by different letters are significantly different as judged by LSD at $p<0.05$. Where: $\mathrm{Mo}=$ stands for moisture content, $\mathrm{Pr}=$ protein contents, $\mathrm{C}$. fat=crude fat (oil contents) and $\mathrm{CHO}=$ carbohydrate contents of sesame oil seed crops.

\subsection{Physicochemical Properties of Sesame Oil Productions}

The physicochemical properties of Sesame oil seed crops are presented in Table 2. The analysis of variance indicated that Saponification values of Sesame seed was highly significant $(\mathrm{P}<0.001)$ different among varieties $($ Table 2$)$. Both Mehalo-80 (199.56 mgKOH/g) and Serkamo (199.60 $\mathrm{mgKOH} / \mathrm{g}$ ) have the highest saponification value followed by the lowest one from Abasena $(184.47 \mathrm{mgKOH} / \mathrm{g})$. Saponification value is a measure of oxidation during storage condition. Oil volatility increases with saponification values. It enhances the quality of the oil because it shows the presence of lower molecular weight components in $1 \mathrm{~g}$ of the oil which will yield more energy on combustion [18]. Its lowest value indicated that the oil may not be used for productions of soap. As a cited by Matthew [19] which reported by Pearson (1976) that, oils with high saponification values contain high proportion of lower fatty acids. Therefore, the low saponification value of some contains high proportion of higher fatty acid and can be regarded as non-edible oils.

The specific gravity was highly significantly $(\mathrm{P}<0.001)$ affected by varieties (Table 2) and ranged between 0.85 to 0.90 . This difference in specific gravity of oils may be due to genetic variability of seed crops and it depends on their fatty acid composition and temperature [20]. The acid value is an indication of the quality of fatty acids in oil and ranged from 15.18 to 33.15 which was significantly $(\mathrm{P}<0.001)$ different among varieties. The lower the acid value, the more stable the oil over a long period of time, protect against 
peroxidation. It is an indicator for edibility of oil [21]. High acid value in oil such as Abasena (33.15) indicates that the oil may not be suitable for cooking, but used for paints and liquid soap preparation [21, 22].

Thousand Seed Weight (TSW) of sesame verities determined at $4.4 \%$ to $4.8 \%$ moisture level is presented in Table 2. It was determined using seed counter, and the maximum TSW was found in S (3.63 g), while the lowest was recorded at Abasena (2.72 g). The recorded refractive index (RI) of sesame oil at different temperature were significantly $(\mathrm{P}<0.001)$ different. The mean $(1.46)$ recorded values of RI of sesame varieties was the same with mean values of RI of ground nut (1.47) and cotton (1.46) oil seed crops $[23,24]$ respectively. Refractive index of oil is the ratio of speed of light at a defined wavelength to its speed in the oil itself. RI varies with wave length and temperature, the degree and type of unsaturation.

Table 2. Oil characterizations of ten selected sesame varieties.

\begin{tabular}{|c|c|c|c|c|c|c|c|c|}
\hline Varieties & SV (mgKOH/g) & $\mathrm{SG}(\mathrm{g} / \mathrm{cm} 3)$ & TSW (g) & Pu (\%) & AV $(\mathrm{KOH} / \mathrm{g})$ & RI (\%) & $\begin{array}{l}\text { EV } \\
\text { (mgKOH/g) }\end{array}$ & FFA $(\%)$ \\
\hline $\mathrm{T}-85$ & $198.39 \pm 0.130^{\mathrm{b}}$ & $0.90 \pm 0.012^{\mathrm{a}}$ & $3.13 \pm 0.045^{\mathrm{f}}$ & $98 \pm 0.000^{\mathrm{a}}$ & $15.48 \pm 0.272^{h}$ & $1.47 \pm 0.000^{\mathrm{a}}$ & $182.90 \pm 0.402^{\mathrm{a}}$ & $7.79 \pm 0.137^{h}$ \\
\hline Kalafo-74 & $190.66 \pm 0.576^{\mathrm{e}}$ & $0.85 \pm 0.020^{c}$ & $3.40 \pm 0.040^{\mathrm{b}}$ & $97.5 \pm 0.500^{a b}$ & $17.22 \pm 0.210^{\mathrm{g}}$ & $1.46 \pm 0.000^{\mathrm{b}}$ & $173.44 \pm 0.760^{\mathrm{d}}$ & $8.66 \pm 0.110^{\mathrm{g}}$ \\
\hline E & $194.30 \pm 0.410^{c}$ & $0.89 \pm 0.000^{\mathrm{ab}}$ & $3.11 \pm 0.000^{\mathrm{f}}$ & $95.5 \pm 0.500^{\mathrm{e}}$ & $23.19 \pm 0.072^{\mathrm{d}}$ & $1.46 \pm 0.000^{\mathrm{b}}$ & $171.12 \pm 0.340^{\mathrm{e}}$ & $11.66 \pm 0.040^{\mathrm{d}}$ \\
\hline S & $194.69 \pm 0.445^{\mathrm{c}}$ & $0.90 \pm 0.010^{\mathrm{a}}$ & $3.63 \pm 0.000^{\mathrm{a}}$ & $93.5 \pm 0.500^{\mathrm{f}}$ & $15.18 \pm 0.111^{h}$ & $1.46 \pm 0.000^{\mathrm{b}}$ & $179.51 \pm 0.475^{\mathrm{c}}$ & $7.63 \pm 0.050^{h}$ \\
\hline Mehalo-80 & $199.56 \pm 0.120^{\mathrm{a}}$ & $0.89 \pm 0.000^{\mathrm{ab}}$ & $3.57 \pm 0.010^{b c}$ & $96.50 \pm 0.559^{\mathrm{dc}}$ & $17.97 \pm 0.042^{f}$ & $1.46 \pm 0.000^{b}$ & $181.59 \pm 0.160^{\mathrm{b}}$ & $9.04 \pm 0.021^{\mathrm{f}}$ \\
\hline Abasena & $184.47 \pm 0.320^{\mathrm{g}}$ & $0.86 \pm 0.010^{\mathrm{c}}$ & $2.72 \pm 0.020^{\mathrm{g}}$ & $97.5 \pm 0.280^{\mathrm{ab}}$ & $33.15 \pm 0.500^{\mathrm{a}}$ & $1.46 \pm 0.000^{\mathrm{b}}$ & $151.32 \pm 0.193^{\mathrm{h}}$ & $16.67 \pm 0.024^{\mathrm{a}}$ \\
\hline Argene & $189.18 \pm 0.500^{f}$ & $0.90 \pm 0.010^{\mathrm{a}}$ & $3.60 \pm 0.020^{\mathrm{ab}}$ & $95.5 \pm 0.000^{\mathrm{e}}$ & $25.06 \pm 0.180^{\mathrm{c}}$ & $1.46 \pm 0.000^{\mathrm{b}}$ & $164.12 \pm 0.320^{\mathrm{g}}$ & $12.66 \pm 0.091^{\mathrm{c}}$ \\
\hline Adi & $198.02 \pm 0.210^{\mathrm{b}}$ & $0.86 \pm 0.010^{c}$ & $3.56 \pm 0.000^{\mathrm{c}}$ & $97.00 \pm 0.000^{\mathrm{bc}}$ & $28.07 \pm 0.620^{\mathrm{b}}$ & $1.47 \pm 0.000^{\mathrm{a}}$ & $169.97 \pm 0.413^{f}$ & $14.12 \pm 0.310^{b}$ \\
\hline Serkamo & $199.60 \pm 0.292^{\mathrm{a}}$ & $0.86 \pm 0.011^{\mathrm{c}}$ & $3.54 \pm 0.010^{c}$ & $96.00 \pm 0.000^{\mathrm{de}}$ & $17.87 \pm 0.050^{\mathrm{f}}$ & $1.47 \pm 0.000^{\mathrm{a}}$ & $181.73 \pm 0.230^{\mathrm{b}}$ & $8.99 \pm 0.032^{\mathrm{f}}$ \\
\hline Tate & $192.26 \pm 0.261^{\mathrm{d}}$ & $0.87 \pm 0.010^{\mathrm{bc}}$ & $3.17 \pm 0.000^{\mathrm{e}}$ & $96.00 \pm 0.000^{\mathrm{de}}$ & $18.78 \pm 0.330^{\mathrm{e}}$ & $1.46 \pm 0.000^{\mathrm{b}}$ & $173.48 \pm 0.590^{\mathrm{d}}$ & $9.45 \pm 0.160^{\mathrm{e}}$ \\
\hline Mean & 194.11 & 0.88 & 3.34 & 96.30 & 21.20 & 1.46 & 172.92 & 10.66 \\
\hline $\operatorname{LSD}(0.05)$ & $0.95 * * *$ & $0.02 * * *$ & $0.04 * * *$ & $0.70 * * *$ & $0.54 * * *$ & $0.00 * *$ & $1.06 * * *$ & $0.27 * * *$ \\
\hline CV $(\%)$ & 0.28 & 1.33 & 0.66 & 0.42 & 1.50 & 0.00 & 0.36 & 1.50 \\
\hline
\end{tabular}

Values are the means of triplicate experiments and reported as mean $\pm \mathrm{S}$. D. CV $(\%)=$ Coefficient of variation, $\mathrm{S}$. $\mathrm{D}=$ standards of deviation of means, means in the same column and within the same treatment category followed by different letters are significantly different as judged by LSD at $\mathrm{p}<0.05$. Where: $\mathrm{SV}=$ saponification value, $\mathrm{SG}=$ Specific gravity $=\mathrm{TSW}=$ thousand seed weight, $\mathrm{Pu}=$ purity, $\mathrm{AV}=$ acid value, $\mathrm{RI}=\mathrm{Refractive}$ index, $\mathrm{EV}=\mathrm{Ester}$ value, and $\mathrm{FFA}=\mathrm{free}$ fatty acid.

RI uses in quality control to check for the purity of materials and to follow hydrogenation and isomerization [25]. The free fatty acid (FFA) values of sesame varieties were significantly $(\mathrm{P}<0.001)$ varied (Table 2$)$. The maximum FFA value was recorded from Abasena (16.67), while both T85 and $\mathrm{S}$ sesame seed crops have the minimum (7.79) and 7.63) FFA values respectively (Table 2). The lower free fatty acid values, the higher the quality of oils. The quantity of free fatty acid in oil is an indicator of its overall quality and it may be formed through hydrolysis or in the advanced stages of oxidation. An excessive amount of free fatty acids lowers the smoke point of oil and will cause 'popping' of the oil during cooking.

\section{Conclusion}

The main goal of this study was based on the assessments of the status of improved and released of different Ethiopian oil crops of Sesame varieties. The study was carried out with the objectives determining the proximate composition and physiochemical parameter analysis of those Ethiopian Oil crops which released and improved in Ethiopian Agricultural Research, Werer Agricultural Research Center. The analysis of variance indicated that, these ten improved and released Ethiopian oil seed crops have significant variations on proximate composition and on their physico chemical parameters. These differences may be due to the reason of different agronomical practice and their genetic modifications. On average, from these ten seed oil crops, Abasena have better oil contents due to the productions of crude fat/oil contents. But due to its lowest saponification and maximum free fatty acids values with the higher acid value from Abasena oil seed crops, it indicated that the oil is not comfortable for cooking purpose as compared with the remain nine oil seed crops. However, it is recommended that further studies should be carried out on the determination of the fatty acid profiles of these improved and released Ethiopian oil seed crops. In addition to these breeders and the nutritionist in collaborations would be checked the nutritional compositions and fatty acid profiles across location for these selected Ethiopian sesame oil seed varieties.

\section{Acknowledgements}

The authors gratefully acknowledge the financial support from Ethiopian Institute of Agricultural Research (EIAR), Food science and nutritional research directorate. We are also thankful to Werer Agricultural Research Centre (WARC) oil seed crops research staff for providing the sesame varieties used in this study. 


\section{References}

[1] CSA (Central Statistical Agency). (2015). Agricultural Sample Survey for the 2014/2015 crop season. Volume I. Report on Area and Production of Major crops for Private Peasant Holdings (Meher Season). Statistical Bulletin 278. FDRE/CSA, Addis Ababa, Ethiopia.

[2] Wijnands, J. H. M. Meijerik and EN van Loo. (2011). Soybean and sunflower seeds production opportunities in Ethiopia. 31-43pp. In: Geremew, T., Adugna, W. and Dereje, G. (eds.). Oilseeds: Engine for Ethiopian Economic Development. EIAR, Addis Ababa, Ethiopia.

[3] Ajala, A. S., \& Adeleke, S. A. (2014). Effect of drying temperatures on physicochemical properties and oil yield of African star apple (Chrysophyllum alibidum) seeds. G. J. E. D. T., 3 (3): 12-16.

[4] Joshi, A. R. (1961). Sesame, 1st edn. The Macmillan Company, Collier-Macmillan Ltd, London, pp. 1-21.

[5] Irvine, F. R. (1969). West African Crops, 3rd edn, Vol. II. Oxford University Press, London, pp. 71-3. Joshi, A. R. (1961). Sesame, 1st edn. The Macmillan.

[6] Ochse, J. J., Soule, J. O. \& Wehlburg, M. J. (1966). Tropical and Subtropical Agriculture, Vol. II. The Macmillan Company, Collier-Macmillan Ltd, London, pp. 1088-93.

[7] Associations of Analytical Chemistry (AOAC).,(2000). Aproved methods for mositure in flour. method 925.09. Official Method of Analysis of AOAC International, 2: 1.

[8] Associations of Analytical Chemistry (AOAC).,(2000). Aproved methods for Ash in flour. method 923.03. Official Method of Analysis of AOAC International, 2: 1.

[9] Associations of Analytical Chemistry (AOAC)., (2000). Aproved method for Protein in grains. Method 979.09. Official Method of Analysis of AOAC International, 30-34.

[10] Thiex, N. J., S. Anderson and B. Gildemeister (2003). "Crude fat, diethyl ether extraction, in feed, cereal grain, and forage (Randall/Soxtec/submersion method): collaborative study." Journal of AOAC International 86 (5): 888-898.

[11] Kaswurm, V., T.-T. Nguyen, T. Maischberger, K. D. KulbeandH. Michlmayr. (2013). Evaluation of the food grade expression systems NICE and pSIP for the production of 2,5diketo-D-gluconic acid reductase from Corynebacterium glutamicum. AMB Express 3: 7.

[12] Marín, F. R., C. Soler-Rivas, O. Benavente-García, J. Castillo and J. A. Pérez-Alvarez. (2007). Byproducts from different citrus processes as a source of customized functional fibres. Food Chem. 100: 736-741.
[13] Mohan, S. (2009). Fatty acid composition of Baccaurea courtallensis Muell. Arg seed oil: An endemic species of western Ghats, India. Journal of the American Oil Chemists' Society 86 : 1017-1019.

[14] Singh, M., R. Charde and M. M. Charde. (2015). Determination of Calcipotriene, its forced degradation and impurity analysis by HPLC. International Journal of Pharmacy \& Life Sciences.

[15] Kemal Ünal. $M$ and Hasan Yalçın (2008). Proximate composition of Turkish sesame seeds and characterization of their oils, ENERO-MARZO, 23-26.

[16] Dashak D. A\&Fali C. N. (1993). Chemical composition of four varieties of Nigerian benniseed (Sesamum indicum). Food Chemistry 47, 253-255.

[17] Farooq Anwar, Ghulam Mustafa Kamal, Farooq Nadeem and Ghulam Shabir. (2015) Variations of quality characteristics among oils of different soybean varietiesJournal of King Saud University - Science.

[18] Engler, C. R., \& Johnson, L. A. (1983). Effects of processing and chemical characteristics of plant oils on performance of an indirect-injection diesel engine, Journal of American Oil Chemical Society, 60 (8), 1592-1596.

[19] Matthew O. A., Hashim I. Ibrahim H, and O. Bamidele T. O (2015). Physicochemical Characteristics of the Oils Extracted from Some Nigerian Plant Foods - A Review.

[20] Fakhri, N. A., \& Qadir, H. K. (2011). Journal of Environmental Science and Engineering, 5, 844-849.

[21] Aremu, M. O., Olaofe, O., \&Akintayo, E. T. (2006a). Chemical composition and physicochemical characteristics of two varieties of bambara groundnut (Vignasubterrenea) flours. J. Applied Sciences, 6 (9), 1900-1903.

[22] Akintayo, E. T. (2004). Characteristics and composition of ParkiaBiglobbossa and Jatropha Curcas oils and cakes. Bioresour. Technology, 92, 307-310.

[23] Zerihun M, Berhe H.(2018). Comparative Assessment of Some Physicochemical Properties of Different Groundnut Varieties and Oil Yield in Afar Region, Ethiopia. Acad. Res. J. Agri. Sci. Res. 6 (2).

[24] Zerihun M., Berhe H., (2018). Physicochemical properties of Cotton seeds oil and its comparison with released and improved cotton varieties in Ethiopia. Acad. Res. J. Agri. Sci. Res. 6 (7): 443-452.

[25] Hoffman, G. (1986). Quality control in food industry, food science and technology series of monographs. 